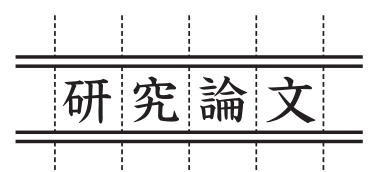

\title{
素材評価技術によるスラブの清浄性と流動の定量化 \\ Quantification of Cleanliness Characteristics and Molten Steel Flow of the Slab by Material Evaluation Technology
}

\author{
笠井宣文*・井口 学** \\ Norifumi KASAI* and Manabu IGUCHI**
}

(Received June 11, 2007)

\begin{abstract}
Dispersion behavior of inclusions is influenced by molten steel flow in a continuous casting mold. The analysis of molten steel flow in the mold has been performed by using techniques such as three-dimensional numerical simulation and cold model experiments. However, these techniques cannot reveal the cleanliness level of inclusions in the mold directly. Therefore we focus in this study on some parameters for characterizing the flow of molten steel in the mold and the cleanliness level of the steel. The molten steel flow in the mold can be inferred from the solidification structure and the cleanliness can be evaluated from the observation of the surface of the slab containing inclusions. An index is introduced on the basis of the mold width and casting speed for an understanding of the relationship between the molten steel flow in the mold and the properties of inclusions in the steel products. The main findings can be summarized as follows:

(1) The inclusion distribution under the slab surface is affected by the fluctuation of molten steel at the meniscus. The fluctuation can be estimated from the oscillation mark pitch.

(2) The velocity of molten steel flow at a solidification interface can be estimated from the inclination angle of dendrite structure.

(3) The distribution of inclusions accumulated in the continuous casting curved zone can be evaluated by the above-mentioned index.
\end{abstract}

Key word: continuous casting, mold, inclusions, molten steel flow, evaluation technology

\section{1. 緒 言}

1997 年 12 月に京都において開かれた「気候変動枠組条 約第 3 回締結国会議 (COP3)」以降、地球温暖化問題に対 する関心が高まり、2005 年 2 月 16 日に京都議定書 ${ }^{1)}$ が発 効されて以降は、産学官合同で具体的な取り組みがなされ つつある。

例えば、自動車メーカーにおいては $\mathrm{CO}_{2}$ 削減を目的とし て、ハイブリットカーの開発や、自動車の構成部材を高強 度化することによる軽量化などの燃費向上対策やリサイク ル化を積極的に進めている。

このような背景のもと、圧延等の加工を施す前の鋳片 の品質を保証するうえで、鋼の清浄性不良や中心偏析など の内質欠陥は、いずれも解決すべき重要な課題であり、こ
れまでに多くの技術者によって多大な努力が払われてき た ${ }^{2)-6) 。}$

特に介在物の残存に対しては、製品のサイズや用途、鋼 の組成の違いによって、多くの研究 7)-10) がなされてきてい るが、これらの研究に欠かせないスラブの清浄性評価技術 は、求められる製品品質に合わせた適切な選択がなされ体 系的に整理されつつある ${ }^{11)}$

しかしながら、自動車メーカーをはじめとするユーザー からの要求に応えていくには、従来の評価手法を用いるだ けでは十分ではないと考えられる。

すなわち、評価手法の精度向上や代表性に対する信頼度 の向上といった従来の課題と合わせて、鋼の清浄性やマク 口偏析の生成に関与する溶鋼流動との関係を定量的に把握 したうえで、製造プロセスへ反映させていく必要があるも

*住友金属工業株式会社 鹿島製鉄所（广 314-0014 茨城県鹿嶋市光 3 番地）

Quality Management and Metallurgy Control Section, Quality Management and

Production Planning Department, Sumitomo Metals Industries Ltd., Kashima Steel Works

(3 Hikari Kasima-City Ibaraki 314-0014 Japan)

**北海道大学大学院工学研究科（ $\overline{\mathrm{T}} 060-8628$ 北海道札幌市北区北十三条西八丁目）

Division of Materials Science and Engineering, Graduate School of Engineering, Hokkaido University

(North 13, West 8, Kita-ku, Sapporo, 06-8628 Japan) 


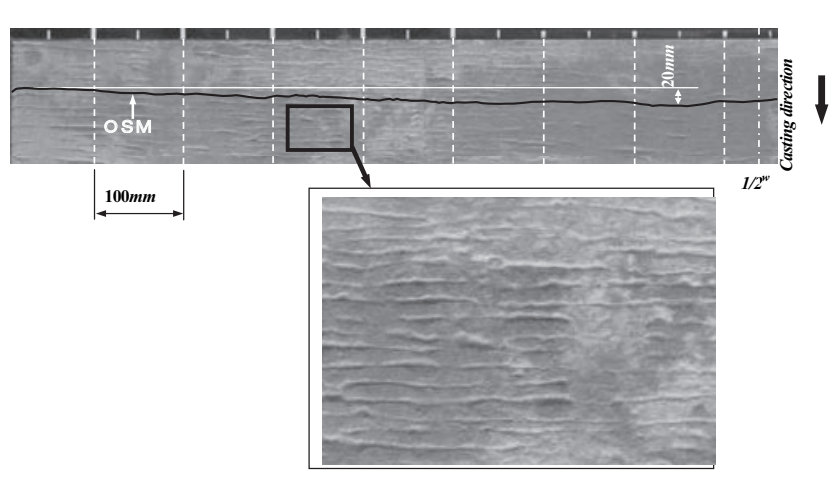

Fig. 1 Photograph of slab surface.

のと考える。

従来、連続鋳造（以下、連鋳と略す）機における操作因 子や測定結果と鋳片における清浄性の関係を求めると、鋳 片の凝固収縮や高温下における測定誤差の影響を受けやす いことから、結果のばらつきが大きくなる問題を有してい たが、このような問題点を解消して、鋳片内の溶鋼流動と 介在物の分散挙動を正確に知ることが、清浄性を向上させ るうえで重要である。

以上の観点から、本研究の目的は、鋳片評価技術によっ て、溶鋼流動に関わる指標と連鋳鋳型内の介在物の動的挙 動を求めることであり、本報では鋳片の評価手法を用いた 清浄性評価と鋳型内溶鋼流動の関係について研究を行った 結果について述べる。

\section{2. 調査方法}

本項では、鋳片の評価手法を用いて、溶鋼流動と清浄性 に関する評価指標を具体的に求める方法について述べる。

\section{1 鋳片評価試験法による 鋳型内溶鋼流動の評価技術}

2.1.1 鋳型内湯面変動指標の求め方

鋳型内における湯面変動量は鋳造中に測定される。測定 結果は鋳造異常の有無、またはスラブ表面と表皮下の久陥 との関係を求めるために用いられている。

しかしながら、鋳片自体の凝固収縮等の影響があり、鋳 造中に測定される正確な湯面変動量を鋳片品質に直接反映 させることは難しい。

そこで、鋳片を調べることで鋳型内湯面変動を表わす指 標を求める方法について検討を行った。

Fig. 1 に酸洗後のスラブ表面の一例を示す。

オッシレーションマークの形状は、マークが形成される 時点のメニスカスの形状である。短辺側と幅中央部では鋳 造方向で約 $20 \mathrm{~mm}$ 程度の差が認められる。この差は吐出噴 流が鋳型短辺に衝突して上昇する流れの影響によるもので ある。

また、マークピッチは不均一であり、仔細に観察をする とスラブ幅方向においてマークが重なっている個所も認め られた。

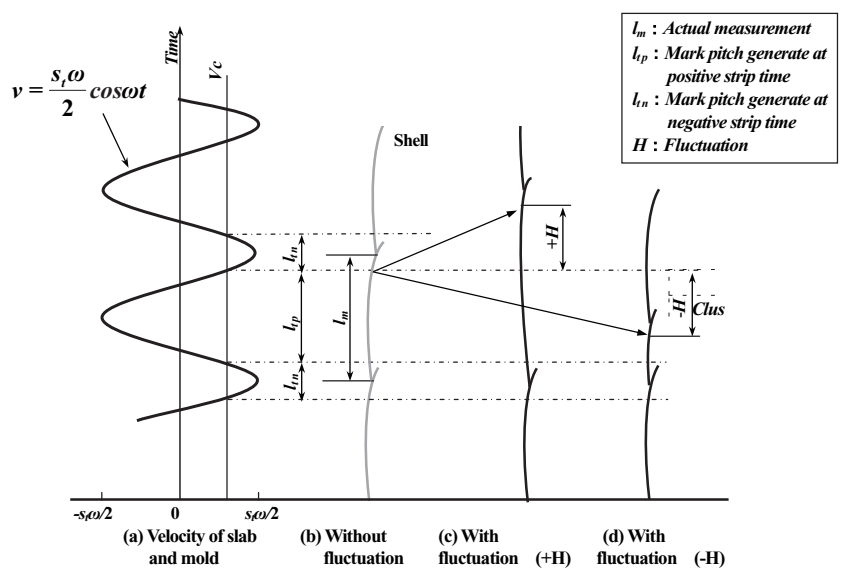

Fig. 2 The way of finding $\mathrm{H}_{\text {osm }}$ from the oscillation mark pitch.

これらの観察結果から、鋳型内における溶鋼流動がオッ シレーションマークの形成に対して影響を及ぼしているこ とが推察される。

オッシレーションマークの生成機構は、鋳型がサイン 波形によって振動を与えられる場合では、ポジティブ期に 凝固殼が生成してネガティブ期にマークが形成される ${ }^{12)}$

(Fig.2(a))

そのために、理論上のマークピッチ（1r) は一定となり、 式 (1) で求めることができる。(Fig.2(b))

しかしながら、メニスカスにおいて溶鋼流動に伴う湯面 変動が生じた場合、実際のマークピッチ $\left(1_{\mathrm{m}}\right)$ は一定の大 きさにはならない。

湯面変動によって湯面が上昇する場合は、マークピッチ は理論值よりも大きくなり、 $1_{\mathrm{m}}$ は式 (2)で表わすことがで きる。一方、湯面変動によって湯面が下降する場合は、マー クピッチは理論值よりも大きくなり、 $1_{\mathrm{m}}$ は式 (3) で表わされ る。(Fig. 2(c), Fig. 2(d))

すなわち、凝固シェルが生成するポジティブ期に湯面変 動が生じることで $1_{\mathrm{m}}$ は不均一になる。

以上のことから、溶鋼流動に伴う湯面変動を評価する指 標はオッシレーションマークピッチを統計的に処理するこ とで得ることができる。

具体的な手法としては、任意の幅位置において鋳造方向 のオッシレーションマークピッチを測定して、式 (4)に示 す指標を湯面変動指数 $\left(\mathrm{H}_{\mathrm{osm}}\right)$ とした。

上述した検討内容の適用結果は第 3.1 項において詳述す る。

$$
\begin{aligned}
& \mathbf{l r}=\mathbf{V}_{\mathrm{c}} / \pi \mathbf{f} \cos ^{-1}\left(-\mathrm{V}_{\mathrm{c}} / \pi \mathbf{s}_{\mathbf{f}} \mathbf{f}\right) \\
& \mathbf{l}_{\mathrm{m}}=\mathrm{I}_{\mathrm{r}}+\mathbf{H} \\
& \mathbf{l}_{\mathrm{m}}=\mathrm{l}_{\mathrm{r}}-\mathrm{H} \\
& \mathbf{H}_{\text {osm }}=\text { STD }_{\mathrm{mp}} / \mathrm{AVE}_{\mathrm{mp}}
\end{aligned}
$$

ここで、 $1_{\mathrm{r}}$ はマークピッチの理論值、 $1_{\mathrm{m}}$ はマークピッチの 

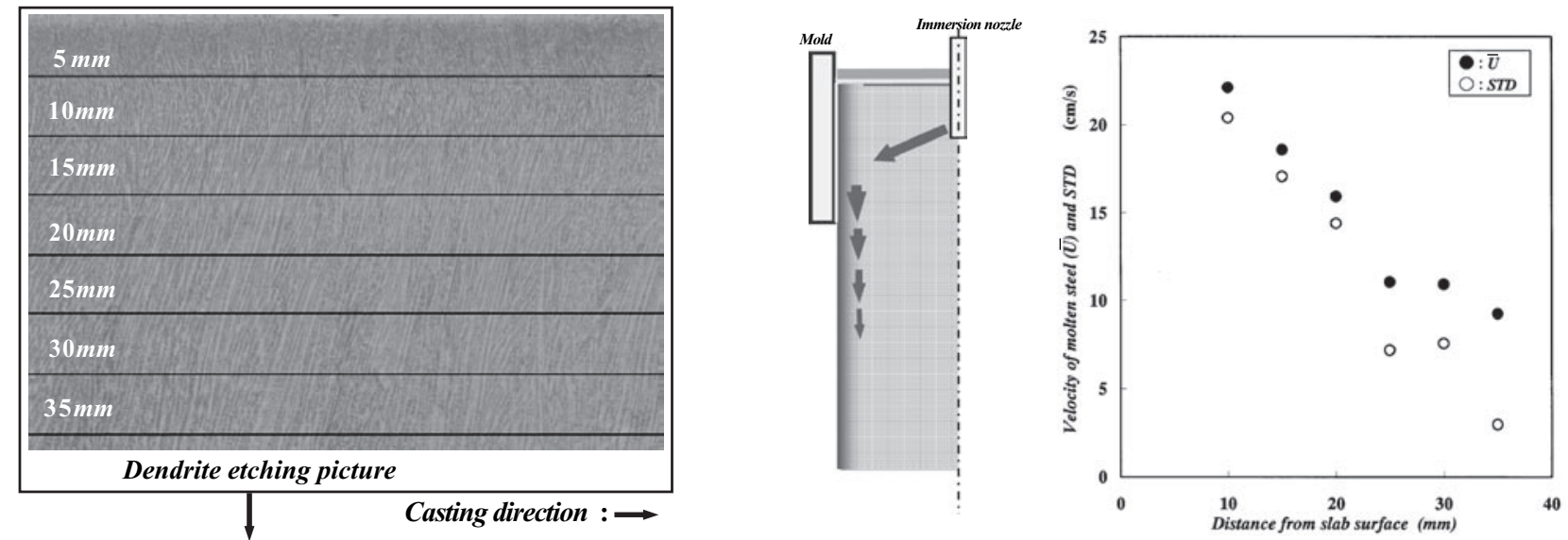

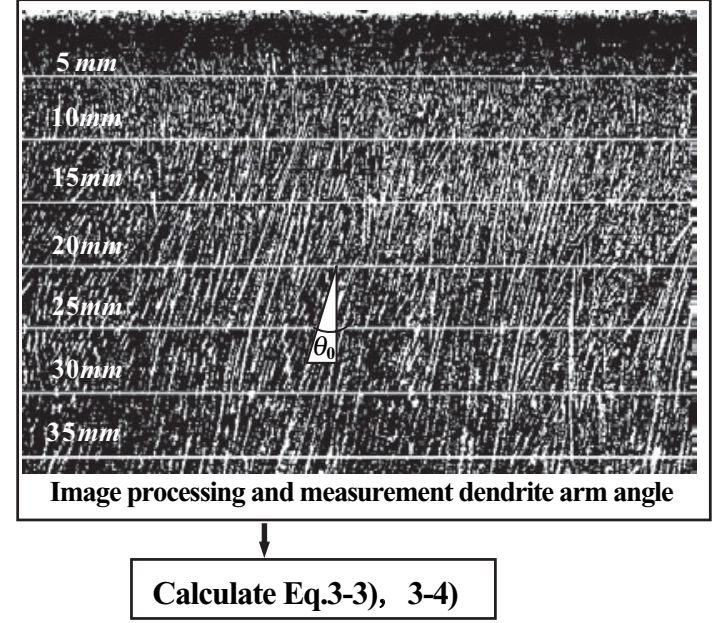

Fig. 3 The example of deflection angle of dendrite measurement by the way of analyzing an image.

実測值、 $\mathrm{H}$ は湯面変動量であり、 $\mathrm{V}_{\mathrm{c}}$ は鋳造速度、f $\mathrm{f}$ はオッ シレーションサイクル、 $\mathrm{S}_{\mathrm{t}}$ はオッシレーションストローク である。また、 $\mathrm{H}_{\mathrm{osm}}$ は湯面変動指数、 $\mathrm{STD}_{\mathrm{mp}}$ はオッシレーショ ンマークピッチの標準偏差、 $\mathrm{AVE}_{\mathrm{mp}}$ はマークピッチの平均 值をそれぞれ

\subsection{2 凝固界面における溶鋼流速}

高橋らは凝固界面における溶鋼流速はデンドライト主軸 の偏向角と凝固速度から、定量的な関係が存在することを 明らかにしている13)。また、岡野ら 14) は高橋らのデータか ら、式(5)、(6)を得ている。

$$
\begin{aligned}
\ln U= & \left(\theta_{0}+9.73 \ln V+33.7\right) /(1.45 \ln V+12.5) \\
& U<50 \mathrm{~cm} / \mathrm{s} \\
\ln U= & \left(\theta_{0}+4.8 \ln V+7.2\right) /(0.1 \ln V+5.4) \\
& U \geqq 50 \mathrm{~cm} / \mathrm{s}
\end{aligned}
$$

ここで、 $\theta_{0}$ :デンドライト主軸の偏向角、U: 溶鋼流速、V: 凝固速度である。

デンドライト主軸偏向角測定結果の一例を Fig. 3 に示す。 デンドライト組織は、 $\theta_{0}$ を測定するためにデジタルカ
Fig. 4 The example of different flow velocities of bulk liquid which was found from the deflection angle of dendrite.

メラによって撮影した。

撮影したデンドライト組織の画像は、パーソナルコン ピュータによって画像処理を行い、 $\theta_{0}$ を自動測定するこ とで求めた。

本方法によって、従来と比較して多くの測定点数を正確 に求めることが可能となった。

Fig. 4 に測定結果の一例を示す。測定用試料は凝固シェ ル界面における下降流の流速を測定することを目的に鋳片 の短辺 $1 / 2$ 厚み位置から切り出した。

Uは吐出噴流が短辺部に衝突する位置（シェル厚み $10 \mathrm{~mm}$ 位置）から離れるにしたがい小さくなっており、下 降流の挙動をよく表わしている。

また、測定デー夕数が増えることで、流速の標準偏差を 求めることが可能となり、流動制御の効果を表わすひとつ の指標として適用可能となった。

スラブのUならびに $\mathrm{STD}_{\mathrm{de}}$ と介在物の分散挙動の関係に ついては、第 3.2 項にて詳述する。

2.1.3 スラブ $1 / 6$ 厚み位置の集積介在物に与える溶鋼流動指 標

1/6 厚み位置集積介在物については精錬条件の違いが介 在物に影響を与えるために、連鋳の操作因子による清浄性 への影響のみを評価することは難しい。

しかしながら、連鋳において溶鋼流動の影響を表わす指 標を持つことは、鋳型内で介在物を浮上させて分離する効 果を向上させる技術開発や改善を行う場合に有効である。

上述した観点から、鋳造中のスラブ内における溶鋼流動 と $1 / 6$ 厚み位置集積介在物の関係について研究を行った。

一般的に、乱流場の流動を表わす指標としては、式 (7) に示すレイノルズ数が用いられる。

$$
\mathbf{R e}=\mathbf{V}_{0} \mathbf{L} / v
$$

ここで、Reはレイノルズ数、 $\mathrm{V}_{0}$ は吐出噴流速度、L は代 


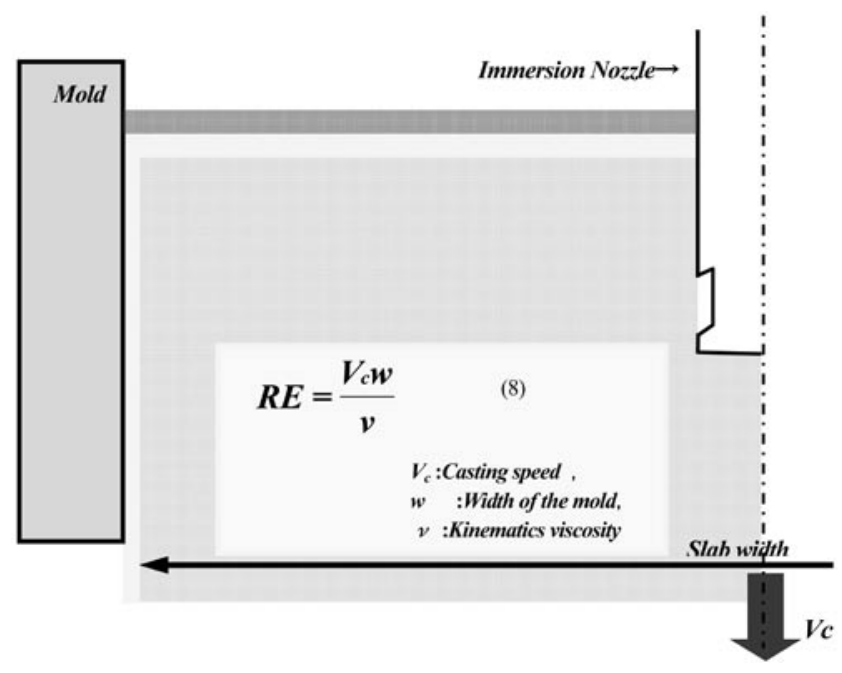

Fig. 5 The way of seeking the molten steel flow evaluation index which used operation factors of continuous casting machine.

表長さ、 $v$ は動粘度である。

しかしながら、スラブ内に持ち込まれる介在物は、鋳造 速度に相当する下降流の影響を強く受ける。また、連鋳に おける操業を考えた場合、操業パラメータを用いた流動を 表わす指標がより実用的である。以上のことから、Fig. 5 に示すように式 (8) から求められる值をスラブ内の溶鋼流 動を表わす指標とした。

$$
\mathbf{R E}=\mathbf{V}_{\mathbf{c}} \mathbf{w} / v
$$

ここで、 $\mathrm{V}_{\mathrm{c}}$ は鋳造速度、 $\mathrm{w}$ は鋳型幅である。

上述した検討内容の適用結果は第 3.3 項において詳述す る。

\section{2 鋳片評価試験法による清浄性の評価}

鋳片における清浄性を評価する上で最も留意すべき点 は、製品用途に応じて適正な評価指標を適用することだと 考える。

すなわち、鋳片では製品用途に応じて問題となる介在物 の種類別に、その大きさ別個数分布を把握することが重要 となってくる。

そのために、清浄性を評価する上で重要なことは評価手 法の特性を把握して、用途に応じた適切な手法を選択する ことだと考える。

そこで、本項では介在物の形態ならびに組成の調査方法 について述べる。

\subsection{1 電解スライム抽出法による清浄性評価}

介在物の形態を観察する手法は、光学顕微鏡による観察 と電解スライム抽出法がある。本項では介在物の形態を 3 次元観察することが可能である電解スライム抽出法につい て述べる。

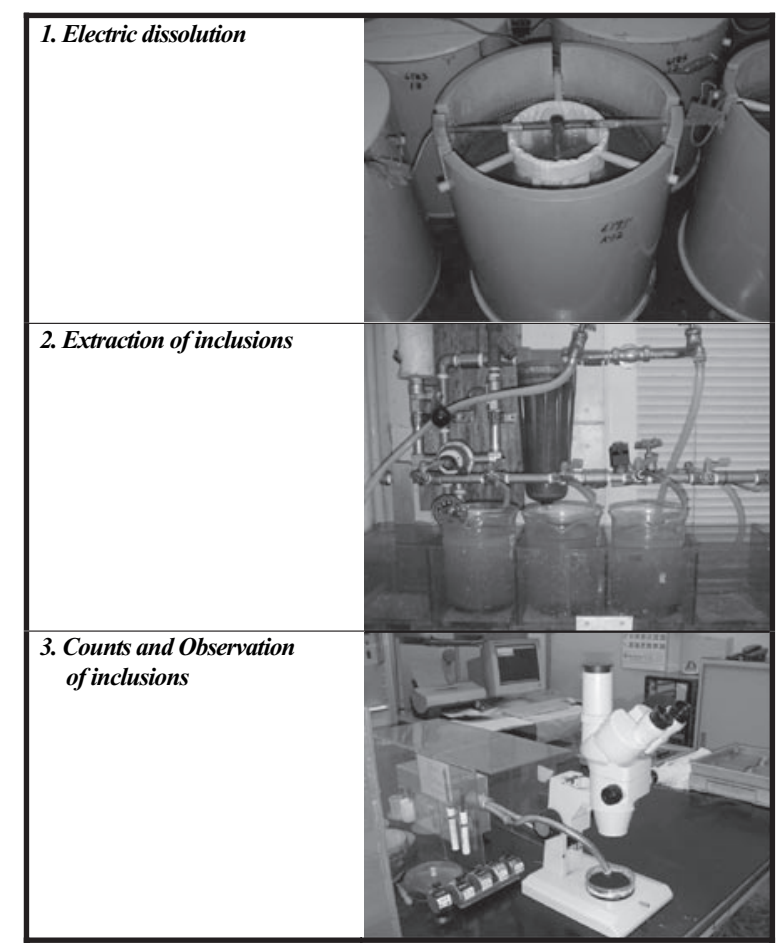

Fig. 6 Extraction method of inclusions by slime.

Fig. 6 に概略を示すが、電解スライム抽出法は鋳片から 採取したサンプルを塩化第一鉄溶液中で電解後、介在物を 抽出してその形態を観察する方法であり、抽出された介在 物は形態ごとにサイズと個数を求めることが可能である。

電解スライム抽出法によって抽出された介在物の形態 は、Fig. 7 に示すようにクラスター、塊状介在物、球状介 在物に区別される。これらの介在物はSEMを用いて介在 物の形態を特定することが可能である。

また、エネルギ分散型 X 線分析法 (Energy Dispersive X-ray Spectrometer: 以下、EDX と略す）によって、介在物 の組成を特定することができる。

EDX による組成分析は SEM と組み合わせることで、介 在物の外観上の特徴と組成を特定することができる。その ため、溶鋼サンプルから製品サンプルまで、その適用範囲 は広い。

2.2.2 精密超音波探傷装置のシステム構成と機能

スラブの清浄性を高周波超音波探傷法によって評価する ことを目的に、信号解析機能とニューラルネットワークを 用いた疵判別機能を導入した全自動探傷システムの開発を 行った ${ }^{15)}$ 。

Fig. 8 に高周波超音波探傷装置のシステム構成と装置外 観を示す。また、Table1に探傷条件を示す。

装置は探触子、超音波発生装置、信号処理装置、三次元 トラバーサーおよび水槽、CRT 等の付帯機器によって構成 されている。 
探傷可能なサンプル形状は $100 \times 100 \times{ }^{3}$ ～ 5mmであり、 表裏面に生じる不感帯を除いた厚み方向の範囲について久 陥を探傷することが可能である。

欠陥種類の判別方法は、バックプロパゲーション型 ニューラルネットワークによって、波形の特徵とあらかじ

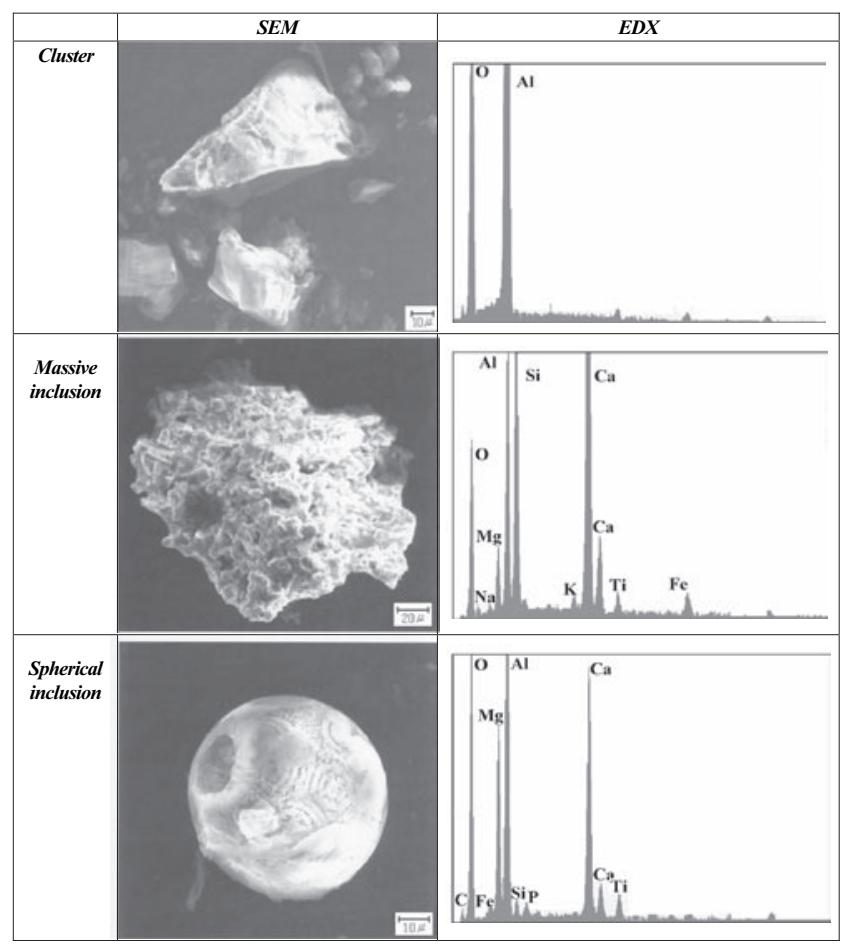

Fig. 7 The form and the composition and the number distribution of the extraction inclusions.
め与えた欠陥種類別の特徵を比較することで、介在物とピ ンホールの判別を行う。本実験において用いた特徴量は欠 陥エコーの位相、S/N 比、振幅などである。

また、介在物種類の弁別は、極值統計法を応用した手法 を用いることで可能である。

\section{3. 実験結果および考察}

\section{1 鋳型内湯面変動による未溶融パウダーの捕捉}

実験は、介在物の形態の違いによる鋳型内の分散挙動を 知ることを目的に行われた。

用いた供試材は、鹿島製鉄所第 3 連鋳機で実験鋳造され たスラブ幅が $1240 \mathrm{~mm}$ から $1600 \mathrm{~mm}$ の低炭素鋼と中炭素鋼 である。鋳造速度は 1.1 から $1.8 \mathrm{~m} / \mathrm{min}$ の範囲である。

Fig. 9 に溶鋼流量と式 (4) から求めた $\mathrm{H}_{\mathrm{osm}}$ との関係を示 す。溶鋼流量が大きくなるのにしたがい、 $\mathrm{H}_{\mathrm{osm}}$ は大きくなっ ている。

この結果から、式 (4) から求められる值は、スラブ表面 ならびに表皮下における介在物の挙動を表わす指標にな

Table 1 Scanning conditions.

\begin{tabular}{|c|c|}
\hline Item & Speck \\
\hline Number of Sample & Max 30 pieces \\
\hline Sample Size & ${ }^{\mathrm{T}} 3.0 \times{ }^{\mathrm{W}} 100 \times{ }^{\mathrm{H}} 100(\mathrm{~mm})$ \\
\hline Sensor prove & $50 \mathrm{MHz}$ Point focus type \\
\hline Focus distance & $12.7(\mathrm{~mm})$ \\
\hline Water pass & $6.7(\mathrm{~mm})$ \\
\hline Scan pitch & $0.03(\mathrm{~mm})$ \\
\hline
\end{tabular}

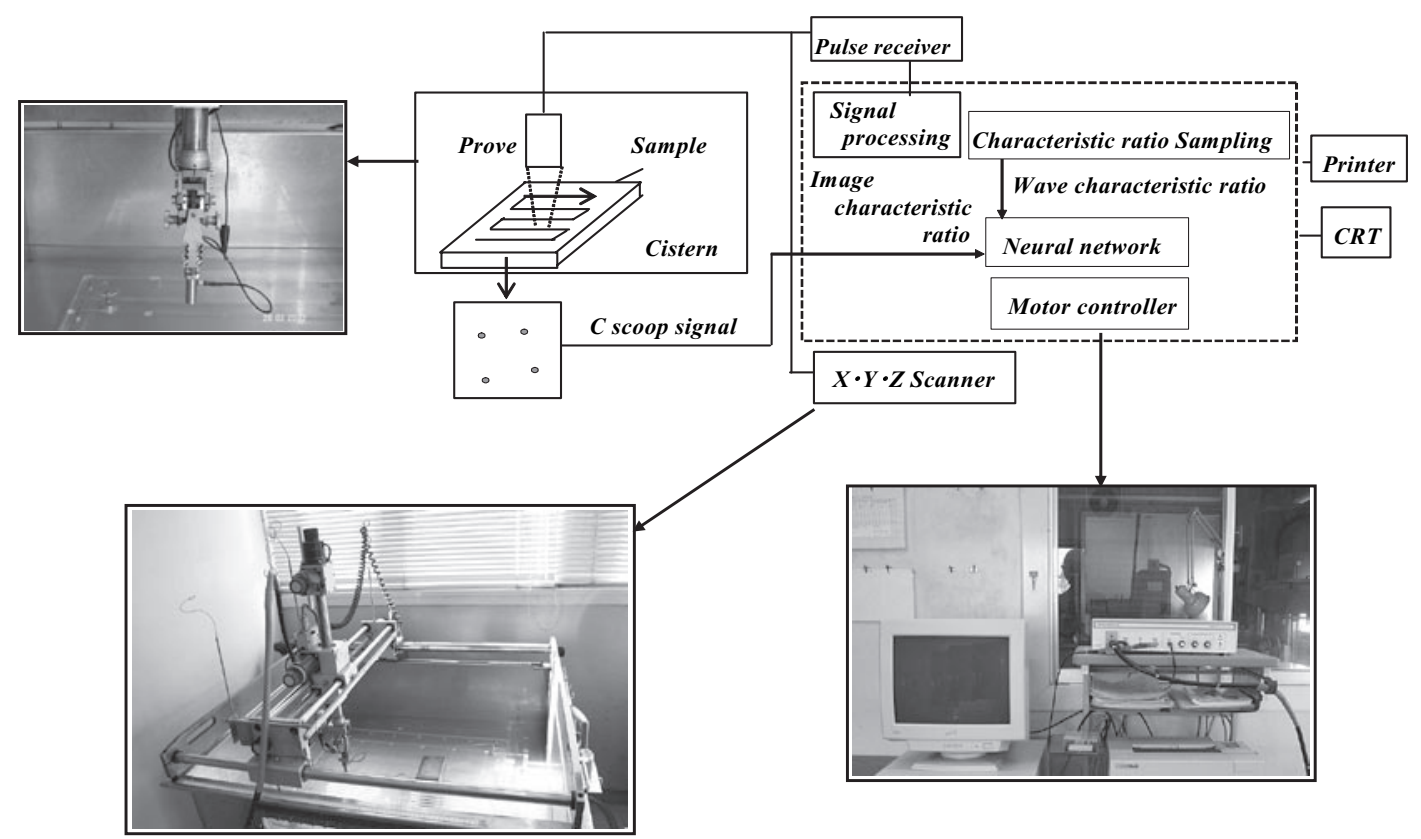

Fig. 8 The outward appearance and the composition of the high frequency supersonic flaw search equipment. 


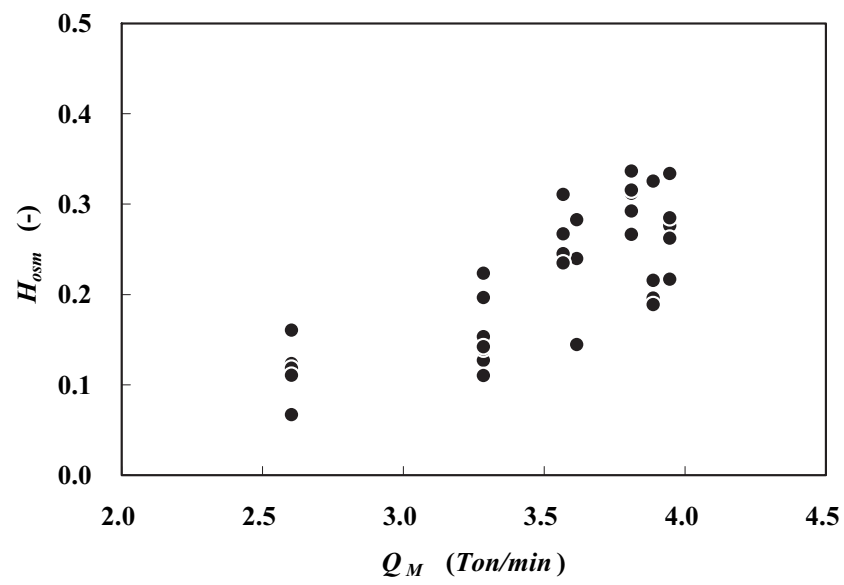

Fig. 9 Relationship between through-put of molten steel and $\mathrm{H}_{\mathrm{osm}}$.

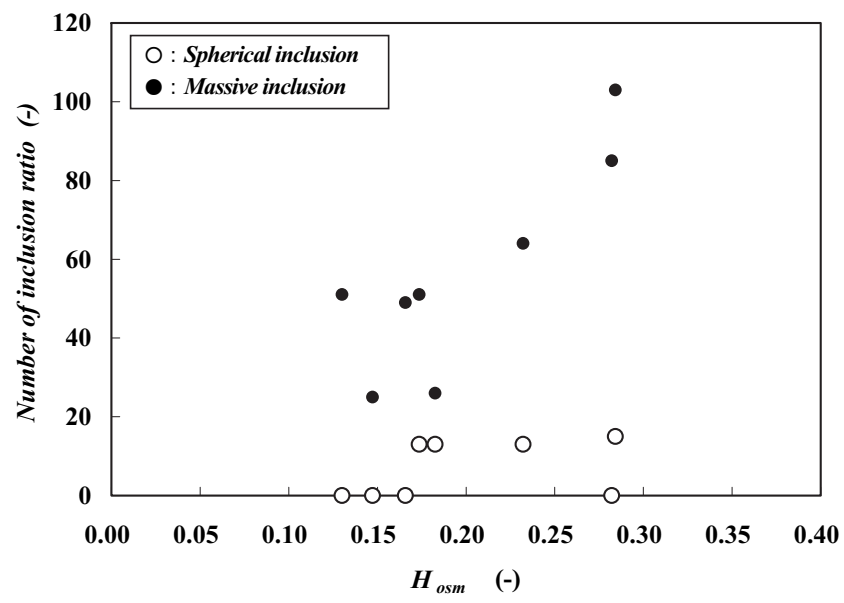

Fig.10 Relationship between $\mathrm{H}_{\mathrm{osm}}$ and number of inclusion ratio.

る。

Fig.10に介在物の形態別に $\mathrm{H}_{\mathrm{osm}}$ と介在物個数指数の関係 を示す。

塊状介在物は $\mathrm{H}_{\mathrm{osm}}$ が大きくなるのにしたがい介在物の個 数が増えているが、球状介在物はその傾向が認められない。

すなわち、塊状介在物は鋳型内の溶鋼流動による湯面変 動の影響を強く受けているのに対して、球状介在物は湯面 変動の影響を受けていない。

また、介在物の形態に着目すると、塊状介在物の多くは 酸化物が焼結した形態が認められる。一方、球状介在物の 場合はいったん溶融した形跡が認められる。

これらのことから、塊状介在物の起源は、湯面変動によっ てパウダーの焼結層もしくは生パウダー層にある酸化物の 粒子が初期凝固シェルに捕足されたものと考えられる。

一方、球状介在物の起源は溶融したパウダーが、鋳型内 において何かしらの原因で巻き込まれ、溶鋼流動によって 分散したものと推察される。

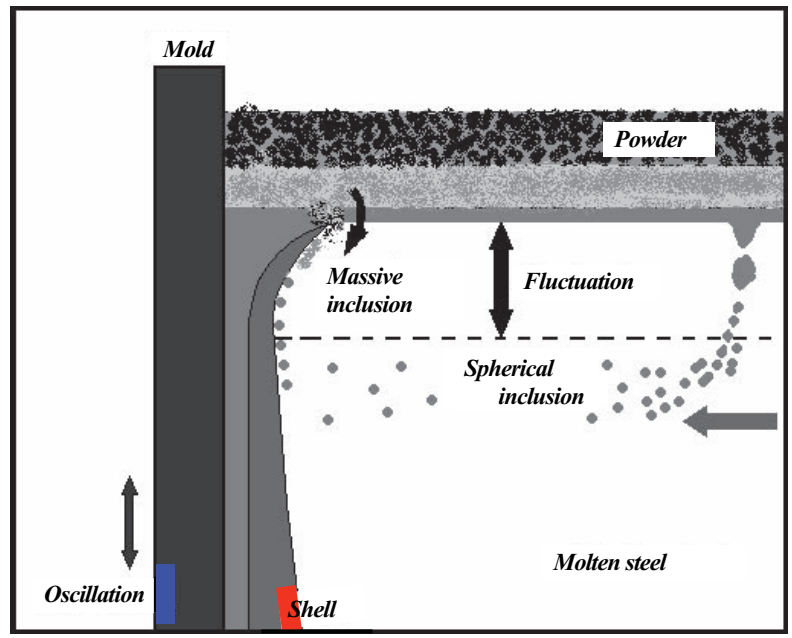

Fig.11 Schematic drawing of the powder involving form.

以上の結果を Fig.11に示す。溶融パウダーの巻き込みに 関するメカニズムについては、別の視点から溶鋼流動との 関係を検討しなくてはならないと考える。

\section{2 デンドライト偏向角測定法による鋳型内溶鋼流動制御 の評価}

デンドライト偏向角測定結果から凝固シェル界面の溶鋼 流速を求める手法を用いて、 EMBr 印加によるスラブ表皮 下における溶鋼流動の評価を行った。

調査に用いた鋳片は、鹿島製鉄所第 1 連鋳機で製造され た幅が $2260 \mathrm{~mm}$ の中炭素鋼のスラブである。

スラブ上面の $1 / 4$ 幅、 $1 / 2$ 幅、3/4 幅位置において、厚み 方向 $70 \mathrm{~mm}$ 、鋳造方向 $150 \mathrm{~mm}$ の範囲について凝固シェル界 面の平均流速と標準偏差を求めた。

また、デンドライトエッチングのサンプルに隣接する位 置で、電解スライム抽出法に用いるサンプルを採取して、 形態別の介在物個数を求めた。サンプルサイズは厚み方向 $10 \mathrm{~mm}$ 、幅方向 $60 \mathrm{~mm}$ 、鋳造方向 $150 \mathrm{~mm}$ である。

$\mathrm{U}$ と $\mathrm{STD}_{\mathrm{de}}$ の関係を Fig.12 に示す。 $\mathrm{EMBr}$ を印加するこ とによってUならびに $\mathrm{STD}_{\mathrm{de}}$ は、 $\mathrm{EMBr}$ を印加しない場合 と比較して、小さくなっていることがわかる。

これらの結果から、浸漬ノズルの吐出口からの噴流に電 磁力を与えることで、流れが分散して、メニスカス方向へ 向かう流れが小さくなることがわかる。

$\mathrm{EMBr}$ 印加の有無によるスラブ表皮下における介在物個 数の比較の一例を Fig.13に示す。クラスターと塊状介在物 は $\mathrm{EMBr}$ を印加することによって減少しているが、球状介 在物は有意差が認められない。

クラスター個数の減少は、 $\mathrm{EMBr}$ を印加することで溶鋼 流動による影響が小さくなり、鋳型内における介在物の浮 上が促進すると考えられる。

また、塊状介在物の減少は、EMBr を印加することでメ 


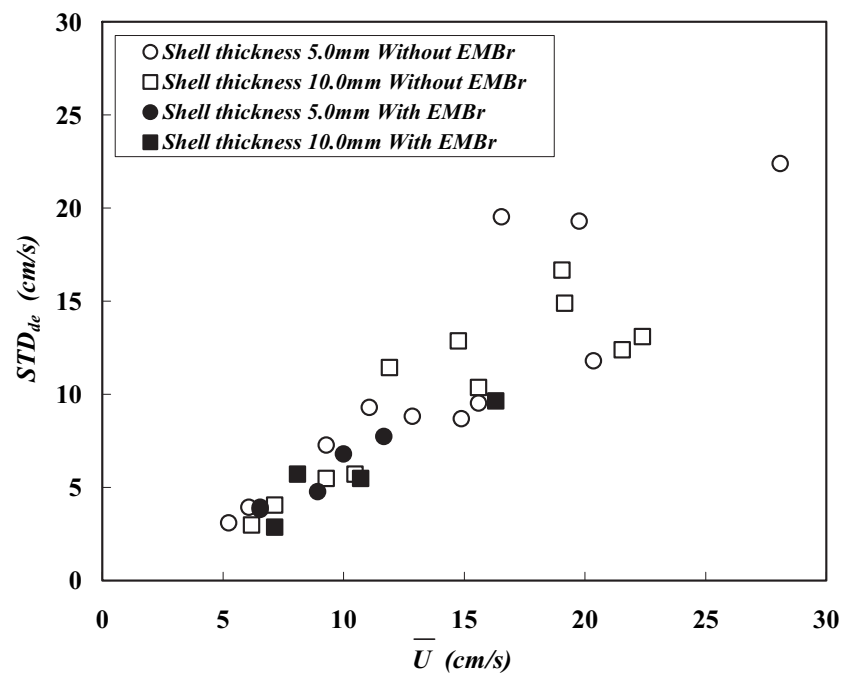

Fig.12 Relationships between $\mathrm{U}$ and $\mathrm{STD}_{\text {de. }}$.

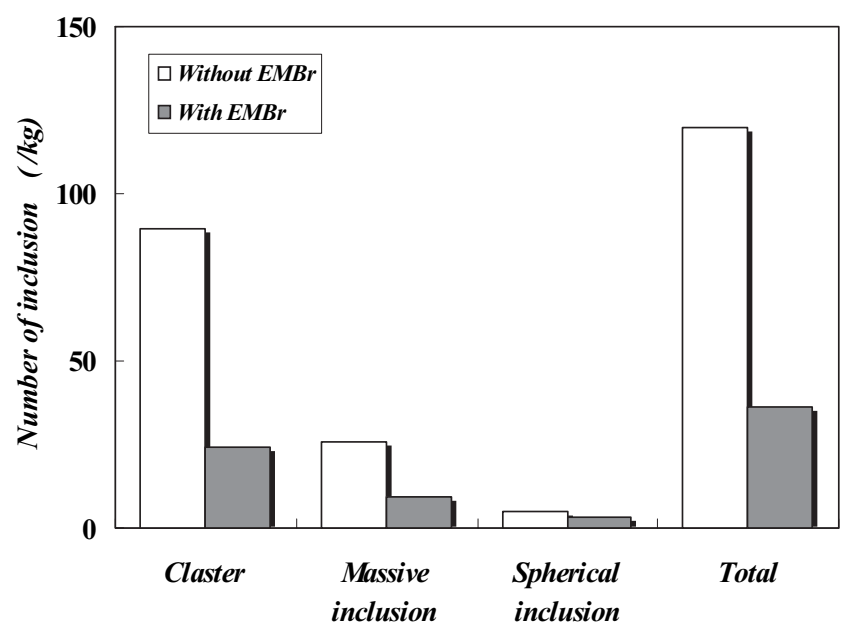

Fig.13 Comparison between number of inclusions with and without EMBr.

ニスカスにおける溶鋼流動による湯面変動が低減したため に初期凝固シェルへの未溶融パウダーの捕捉が低減したこ とによるものと考えられる。

一方、球状介在物の場合は、浸漬ノズル近傍では電磁力 の影響が小さいため、介在物の低減効果が認められなかっ たと考えられる。

\section{3 スラブ $1 / 6$ 厚み位置の集積介在物に与える溶鋼流動の \\ 評価}

介在物の評価では、大きさ別の個数分布が重要となって くる。そこで、1/6厚み位置集積介在物について大きさ別 個数分布を調査した。

調査の対象とした鋼種は鹿島製鉄所第 3 連鋳機で鋳造さ れた低炭素鋼、中炭素鋼、極低炭素鋼である。スラブ幅は $1250 \mathrm{~mm}$ から $1600 \mathrm{~mm}$ 、鋳造速度は $1.1 \mathrm{~m} / \mathrm{min}$ から $1.8 \mathrm{~m} / \mathrm{min}$

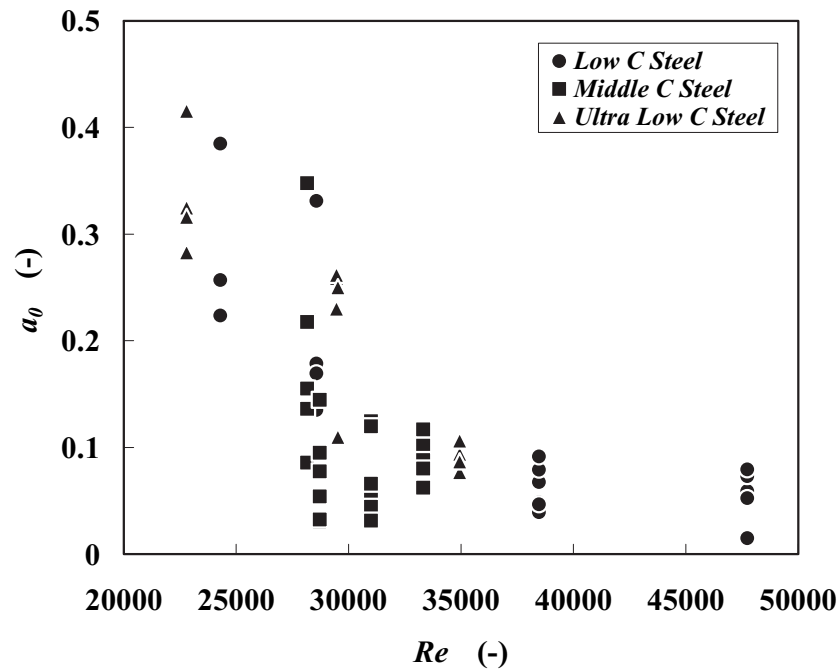

Fig.14 Relationship between $\mathrm{Re}$ and $\mathrm{a}_{0}$.

の範囲である。

サンプルは鋳型内湯面変動などの鋳造状態が安定した状 態で採取した。

介在物の調査は、高周波超音波探傷装置が用いられた。 得られたデータから、スラブ幅位置別の厚み方向個数分布 と大きさ別個数分布を求めて、鋳型内溶鋼流動との関係に ついて解析を行った。

介在物の大きさ別個数分布は同一種類の欠陥の場合、式 (9)によって近似することが出来る。15)

また、介在物分布係数 $\mathrm{a}_{0}$ の值が小さいほど大型介在物が 多いと言える。

$$
\mathbf{y}_{a}=\mathbf{a}_{0} \cdot \exp (-\mathbf{b} \cdot \text { AFA })
$$

ここで、AFA は介在物のサイズ、 $\mathrm{a}_{0} 、 \mathrm{~b}$ は介在物分布係数 である。

Fig.14に結果の一例を示す。REが大きくなると介在物 分布係数 $\mathrm{a}_{0}$ は小さくなる。このことから、集積部には大型 の介在物が増加することがわかる。また、REが約 30000 以上になると、 $\mathrm{a}_{0}$ のばらつきは小さく一定となる傾向が認 められる。

以上の結果から、スラブ厚み方向位置の集積介在物は、 鋳型内における溶鋼流動を表わす指標をもって評価するこ とが可能であると言える。

\section{4. 結 言}

$\mathrm{CO}_{2}$ 削減対応策に応じた鉄鋼素材の品質向上対策に不可 欠である鋳片評価技術について、清浄性と溶鋼流動の評価 手法について研究を行った結果について、その概要を示し た。

本報において示した手法は、溶鋼流動の可視化技術に対 する実証や、操業条件の適正化などに寄与するものと考え 
られる。

\section{References}

1) http://www.mofa.go.jp/mofaj/gaiko/kankyo/kiko/cop3/k_koshi.html 2007. 5. 2

2) A.Kusano, H.Misumi and S.Harada: Tetsu-to-hagane, 82(1996)35-40

3) H.Yamasaki, N.Bessyo, N.Shiga, T.Fujii and H.Umada: CAMP-ISIJ, 4(1991)1251.

4) A.Yamanaka, K.Okamura, T.Kanazawa: Tetsu-to-hagane,82(1996)9991004.

5) T.Watanabe, A.Satou, K.Yoshida, M.Toyoda and M.Kawasaki: CAMP-ISIJ, 2(1989)R51.

6) H.Yasunaka, R.Yamanaka, T.Inoue and T.Saitou: Tetsu-to-Hagane,81(1 995)529-534.

7) Y.Tanizawa, M.Toyoda, T.Hirata and K.Takatani: CAMP-ISIJ,
5(1992)1250

8) K.Mukai: Tetsu-to-hagane, 82(1996)8-14.

9) Y.Shimizu, T.Touge, S.Sasayama, T.Endou, Y.Hayashi and M.Matsui: CAMP-ISIJ, 7(1994)300.

10) H.Yamazoe, T.Shinozuka, J.Yoshiyama, N.Kasai and S.Hiraki: CAMP-ISIJ, 5(1992)1248.

11) Y.Kato, K.Sato, K.Hiraoka and Y.Nuri: Sanyo Technical Report,7-1(2001)59-67.

12) M.Nakato, Y.Habu, T.Emi, K.Sorimachi, T.Koshikawa and H.Kojima: Tetsu-to-hagane, 67(1981)S908.

13) T.Takahashi, K.Ichikawa, M.Kudou and K.Shimahara: Tetsu-to-hagane, 61(1975)2198-2213.

14) S.Okano, T.Nishimura, H.Ooi and T.Chino: Tetsu-to-hagane, 61(1975)2982-2990.

15) N.Kasai, H.Ookubo and T.Nishi: Tetsu-to-hagane, 91(2005)537-545. 